North American Journal of Aquaculture, 1999, v61, n4, p319-325

ISSN: (Print 1522-2055) (Online 1548-8454)

doi: 10.1577/1548-8454(1999)061<0319:UOEMTI>2.0.CO;2

http://afsjournals.org

http://afsjournals.org/loi/naja

http://afsjournals.org/doi/pdf/10.1577/1548-8454\%281999\%29061\%3C0319\%3AUOEMTI\%3E2.0.CO\%3B2

(C) Copyright by the American Fisheries Society 1999 


\title{
Use of Erythrocyte Measurements to Identify Triploid Saugeyes
}

\author{
Mary Ann R. Garcia-Abiado, Konrad Dabrowski,** \\ James E. Christensen, and Sergiusz CZesny \\ School of Natural Resources, The Ohio State University, \\ 2021 Coffey Road, Columbus, Ohio 43210, USA \\ Przemyslaw Bajer \\ Department of Applied Ecology, University of Lodz, \\ PL-90-237, Lodz, Poland
}

\begin{abstract}
The use of erythrocyte size measurements as a possible alternative to flow cytometry for identifying triploid saugeyes (female walleye Stizostedion vitreum $\times$ male sauger $S$. canadense) was evaluated. Blood smear preparations were made from 32 heat-shocked saugeyes (1.0-42.7 g; 52-185 mm total length), which consisted of 12 diploids and 20 triploids, as determined by flow cytometry after blood cells were stained with propidium iodide. The length, width, surface area, and volume of the cell and nucleus of 100 erythrocytes were determined for each fish. The cell and nuclear dimensions were measured at $1,000 \times$ magnification with a calibrated ocular micrometer. Discriminant analysis was used to distinguish diploids and triploids based on their score profiles. Results showed that triploid saugeyes had significantly larger erythrocyte cell and nucleus measurements than their diploid counterparts $(N=32 ; P<$ 0.0001). Erythrocyte measurements correctly distinguished $93.8 \%$ of fish samples as diploids or triploids, but measurements require about $1 \mathrm{~h} /$ fish. The potential applications of this technique for fisheries management and aquaculture are discussed.
\end{abstract}

The production of triploid saugeyes (female walleye Stizostedion vitreum $\times$ male sauger $S$. canadense) offers possible benefits to stocking programs and to aquaculture. Triploidy induction will prevent fertile diploid saugeyes from contaminating parental stocks and producing second generation hybrids. Extensive saugeye reproduction in the Ohio river (White and Schell 1995), Normandy Reservoir, Tennessee (Fiss et al. 1997), and in the Peoria Pool of the Illinois River (Billington et al. 1997) has compromised the genetic integrity of local and downstream parental stocks by producing second generation hybrids. Additionally, triploid saugeyes may be a promising aquaculture commodity for fish farmers in the midwestern United States that have expressed increased interest in raising saugeyes to marketable sizes.

* Corresponding author: dabrowski.1@osu.edu Received October 26, 1998; accepted April 2, 1999
We currently lack a practical technique for fish managers or culturists to use in assessing the success of inducing triploidy in saugeye juveniles for reservoir stocking or grow out. Various techniques have been used to identify ploidy in fish (Table 1; also see Harrell et al. 1998) but among these methods, the measurement of erythrocyte dimensions is the least complicated and is probably applicable to state and commercial hatchery operations. The sizes of blood and other cells correlate with DNA cellular content, and in fishes, variations in the amount of nuclear DNA depend mainly on the ploidy level (see review by Fange 1992). Experimentally, cellular and nuclear dimensions of erythrocytes have been shown to be proportional to ploidy in teleost fishes (Sezaki et al. 1977; Wolters et al. 1982; Beck and Biggers 1983). The accuracy and reliability of this technique for identifying diploids and triploids varied between fish species: 95-100\% in landlocked Atlantic salmon Salmo salar (Benfey et al. 1984), 80-94\% in channel catfish Ictalurus punctatus (Wolters et al. 1982), and $70.8 \%$ in rainbow trout (Tambets et al. 1991). In our study, we evaluated the use of erythrocyte size measurements by light microscopy as a possible alternative to flow cytometry analysis for identifying triploid saugeyes. Flow cytometry is an optical technique that measures particle fluorescence after being stained with a DNA-specific dye such as propidium iodide (Thorgaard et al. 1982; Harrell et al. 1998). This technique has been routinely used to determine ploidy in other percids such as yellow perch and walleye (Malison et al. 1993; Malison and Garcia-Abiado 1996).

\section{Methods}

Blood collection.-Blood samples were collected from 32 heat-shocked saugeyes (1.0-42.7 g; 52-185 mm total length), consisting of 12 diploids and 20 triploids as identified by flow cytometry (see below). Both groups were produced from a large-scale triploidy induction experiment con- 
TABLE 1.- Techniques used to identify ploidy in fish.

\begin{tabular}{lll}
\hline \multicolumn{1}{c}{ Technique } & \multicolumn{1}{c}{ Species examined } & \multicolumn{1}{c}{ Reference } \\
\hline Chromosome counting & $\begin{array}{l}\text { Misgurnus anguillicaudatus } \\
\text { Rainbow trout Oncorhynchus mykiss }\end{array}$ & Arai et al. (1991) \\
& Rainbow trout & Flajshans et al. (1992) \\
Flow cytometry & Grass carp Ctenopharyngodon idella & Thorgaard et al. (1982) \\
& Yellow perch Perca flavescens & Malison et al. (1993) \\
& Walleye Stizostedion vitreum & Malison and Garcia-Abiado (1996) \\
Erythrocyte measurements & & \\
Coulter counter analysis & Grass carp & Wattendorf (1986) \\
& Brown bullhead Ameiurus nebulosus & Cormier et al. (1993) \\
Image analysis & Wels Silurus glanis & Flajshans (1997) \\
Fluorescence microscopy & Asian catfish Clarias macrocephalus & Thititananukij et al. (1996) \\
Light microscopy & Brown trout Salmo trutta & Crozier and Moffett (1989) \\
& Misgurnus anguillicaudatus & Arai et al. (1991) \\
& Red sea bream Pagrus major & Kitamura et al. (1991) \\
& Common carp Cyprinus carpio & Cherfas et al. (1994) \\
Nucleolar organizer region & Rainbow trout & Flajshans et al. (1992) \\
& Pacu Piaractus mesopotamicus & Forest et al. (1994) \\
Tissue measurements & Grass carp & Bonar et al. (1988) \\
\hline
\end{tabular}

ducted on April 2, 1998, using heat shock administered $5 \mathrm{~min}$ after fertilization for $15 \mathrm{~min}$ at 31 $\pm 0.1^{\circ} \mathrm{C}$. These heat shock characteristics were based upon high $(>80 \%)$ triploid rates obtained from our preliminary experiments during the 1997 spring spawning season and during the 1998 offseason walleye spawning (data not shown). The newly hatched larvae were raised in ponds at $\mathrm{He}$ bron State Fish Hatchery, Ohio, for $40 \mathrm{~d}$ before blood sampling. Blood was collected from the caudal vein of each fish by cutting the tail at the caudal peduncle using a sharp scalpel. In larger fish $(>10$ $\mathrm{g}$ ), blood was collected with a heparinized syringe from the caudal vessel. A portion of the blood was fixed in 5\% dimethyl sulfoxide (DMSO; Sigma Chemical Co., St. Louis, Missouri) in isotonic diluent (ISOTON II; Coulter Corp., Miami, Florida) and kept frozen at $-20^{\circ} \mathrm{C}$ until flow cytometry analysis, and the remaining unfixed blood was used for smear preparations.

Flow cytometry analysis.-The blood of each fish was analyzed for ploidy by flow cytometry following techniques in Lin and Dabrowski (1996) with some modifications. Briefly, a small volume $(\sim 10-20 \mu \mathrm{L})$ of blood fixed in 5\% DMSO was transferred to $12-\mathrm{mm} \times 75-\mathrm{mm}$ sterile plastic tubes with snap caps (Fisher Scientific, Pittsburgh, Pennsylvania) containing $800 \mu \mathrm{L}$ propidium iodide stain and $10 \mu \mathrm{L}$ rainbow trout blood (internal standard). The propidium iodide stain was prepared by dissolving $50 \mathrm{mg}$ propidium iodide (P4170; Sigma) and $10 \mathrm{mg}$ ribonuclease A (R-
4875; Sigma) in $1 \mathrm{~L}$ of ISOTON II. The solution was incubated overnight at $4^{\circ} \mathrm{C}$, gently syringed (21- and 26-gauge needles, Becton-Dickinson and Co., Franklin Lakes, New Jersey) and filtered using $60 \mu \mathrm{m}$-Nitex netting (Argent Chemical Laboratories, Redmond, Washington). Flow cytometry analysis was performed on a Coulter EPICS Elite flow cytometer (Coulter Corp., Miami, Florida) equipped with a 488-nm, 15-mW air-cooled Argon laser. A minimum of 10,000 gated cells were collected at a rate of 500 events per second. Propidium iodide signal was measured with a $610-\mathrm{nm}$ long-pass transmission filter and represented in linear mode. Single parameter statistics on sample and internal standard peak positions were generated using a Standard Elite Workstation Software. The ratio of peak positions between diploid saugeyes and rainbow trout internal standard is about $0.3-0.4$, and the ratio of peak positions between triploid saugeyes and rainbow trout internal standard is about 0.5-0.6.

Blood smear preparations.-Blood smears were prepared according to Humason (1979:219-244). Air-dried smears were fixed for $1 \mathrm{~min}$ in methanol, stained with Wright-Giemsa (Sigma) for $1 \mathrm{~min}$, and washed twice in distilled water for $1 \mathrm{~min}$. The length and width of the cell and nucleus of 100 randomly selected erythrocytes were measured under $1,000 \times$ magnification using an ocular micrometer fitted inside the eyepiece $(10 \times$ magnification $)$ of an Olympus compound microscope (model BH2-RFC, Olympus America, Inc., Melville, New 
TABLE 2.-Mean values of erythrocyte cell and nucleus measurements in diploid $(N=12)$ and triploid $(N=20)$ saugeyes, diploid to triploid ratios, and corresponding $F$-values $(P<0.0001)$ for univariate analysis of variance. Diploid and triploid saugeyes were identified by flow cytometry.

\begin{tabular}{lcccc}
\hline Discriminating variable & Diploids & Triploids & Ratio & $F$ \\
\hline Cell & & & & \\
$\quad$ Length $(\mu \mathrm{m})$ & $10.4 \pm 0.9$ & $11.8 \pm 0.3$ & $1: 1.1$ & 43.7 \\
$\quad$ Width $(\mu \mathrm{m})$ & $7.4 \pm 0.5$ & $8.4 \pm 0.6$ & $1: 1.1$ & 26.2 \\
$\quad$ Surface area $\left(\mu \mathrm{m}^{2}\right)$ & $59.6 \pm 6.6$ & $77.2 \pm 5.7$ & $1: 1.3$ & 63.8 \\
$\quad$ Volume $\left(\mu \mathrm{m}^{3}\right)$ & $296.3 \pm 46.4$ & $436.3 \pm 60.7$ & $1: 1.5$ & 47.1 \\
Nucleus & & & & \\
$\quad$ Length $(\mu \mathrm{m})$ & $3.6 \pm 0.7$ & $5.8 \pm 0.3$ & $1: 1.3$ & 52.7 \\
$\quad$ Width $(\mu \mathrm{m})$ & $11.0 \pm 2.1$ & $16.1 \pm 1.8$ & $1: 1.2$ & 34.2 \\
$\quad$ Surface area $\left(\mu \mathrm{m}^{2}\right)$ & $23.0 \pm 5.7$ & $38.9 \pm 7.4$ & $1: 1.7$ & 51.3 \\
$\quad$ Volume $\left(\mu \mathrm{m}^{3}\right)$ & & & & 40.8 \\
\hline
\end{tabular}

York). Cell length, cell width, nucleus length, and nucleus width were recorded. Surface area $(S)$ and volume $(V)$ of both the cell and its nucleus were computed following the formula for ellipsoids or oblate spheroids (Benfey and Sutterlin 1984; Aliah et al. 1990):

$$
\begin{aligned}
& S=\pi(a / 2) \times(b / 2) ; \\
& V=4 / 3 \times \pi(a / 2) \times(b / 2)^{2} ;
\end{aligned}
$$

$a=$ length or major axis of a cell or nucleus, and $b=$ width or minor axis of a cell or nucleus.

Statistical analysis.-Discriminant analysis was used to construct a linear combination of variables that maximally differentiate between predefined groups (Bennett and Bowers 1976; Armitage and Berry 1994). Two groups of saugeyes were defined depending upon the ploidy of each fish: diploids or triploids. A linear combination of the variables was calculated using Fisher's linear discriminant function coefficients of cell length, cell width, cell surface area, cell volume, nucleus width, nucleus surface area, and nucleus volume. Classification functions were determined for each of group of saugeyes. Each fish was then classified on the basis of these functions as belonging either to the diploid group or the triploid group. Cross-validation was supplied using jackknife procedures (Wilkinson 1996). Discriminant analysis was performed using the software Statistical Package for the Social Sciences (SPSS 7.5 for Windows, SPSS, Inc., Chicago, Illinois).

\section{Results}

Similar to red blood cells of other fish, saugeye erythrocytes are oval and elliptical disk-shaped with a compact nucleus. Mean values of length and width, surface area, and volume of triploid saugeye erythrocyte cells and nuclei were significantly larger $(1.1-1.7$ times; $P<0.0001)$ than the values for the corresponding diploid saugeye measurements (Table 2). The ranges of values for each variable, however, were large enough that overlap occurred between ploidy groups (Figure 1).

\section{Differences in Group Centroids}

Wilk's lambda determines whether the discriminant function separates two or more groups significantly on the basis of differences in discriminating variables (Kachigan 1986). Wilk's lambda $(0.27)$ indicated that the diploid and triploid groups had significantly different $(P<0.0001)$ group centroids (i.e., weighted mean values of the discriminating variables) which were calculated from a linear combination of cell length, cell width, cell surface area, cell volume, nucleus length, nucleus width, nucleus surface area, and nucleus volume (Table 3). The centroid for diploids was -2.034 , and the centroid for triploids was 1.221. The scatter plot of the linear combination scores of each fish from the diploid and triploid groups clearly shows that the variables separate the two types of fish (Figure 2).

\section{Classification Results}

Two fish were misclassified from the diploid group. A classification matrix showed that the two fish shown in Figure 2 as the two darkened points closest to zero on the left $y$-axis were not classified correctly. The linear combination of the variables tested (Table 4) correctly classified $93.8 \%$ of the fish samples as diploids or triploids.

\section{Discussion}

Our results with triploid saugeyes are consistent with the findings that the incorporation of a triploid genome in fish causes a significant increase in erythrocyte cell and nucleus measurements (Benfey and Sutterlin 1984; Benfey et al. 1984; Fange 


\section{A. Erythrocyte Cell Measurements}
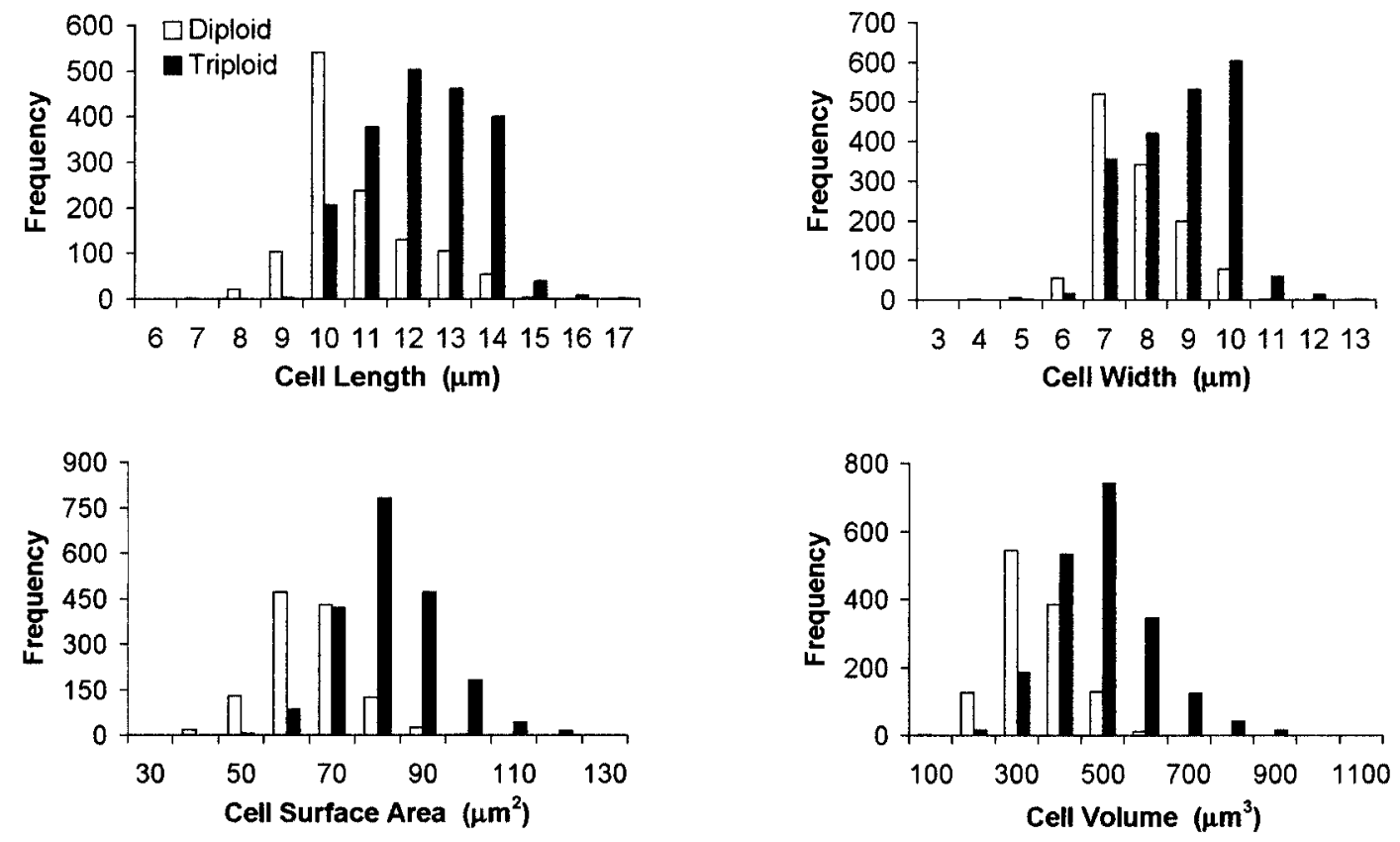

\section{B. Erythrocyte Nucleus Measurements}
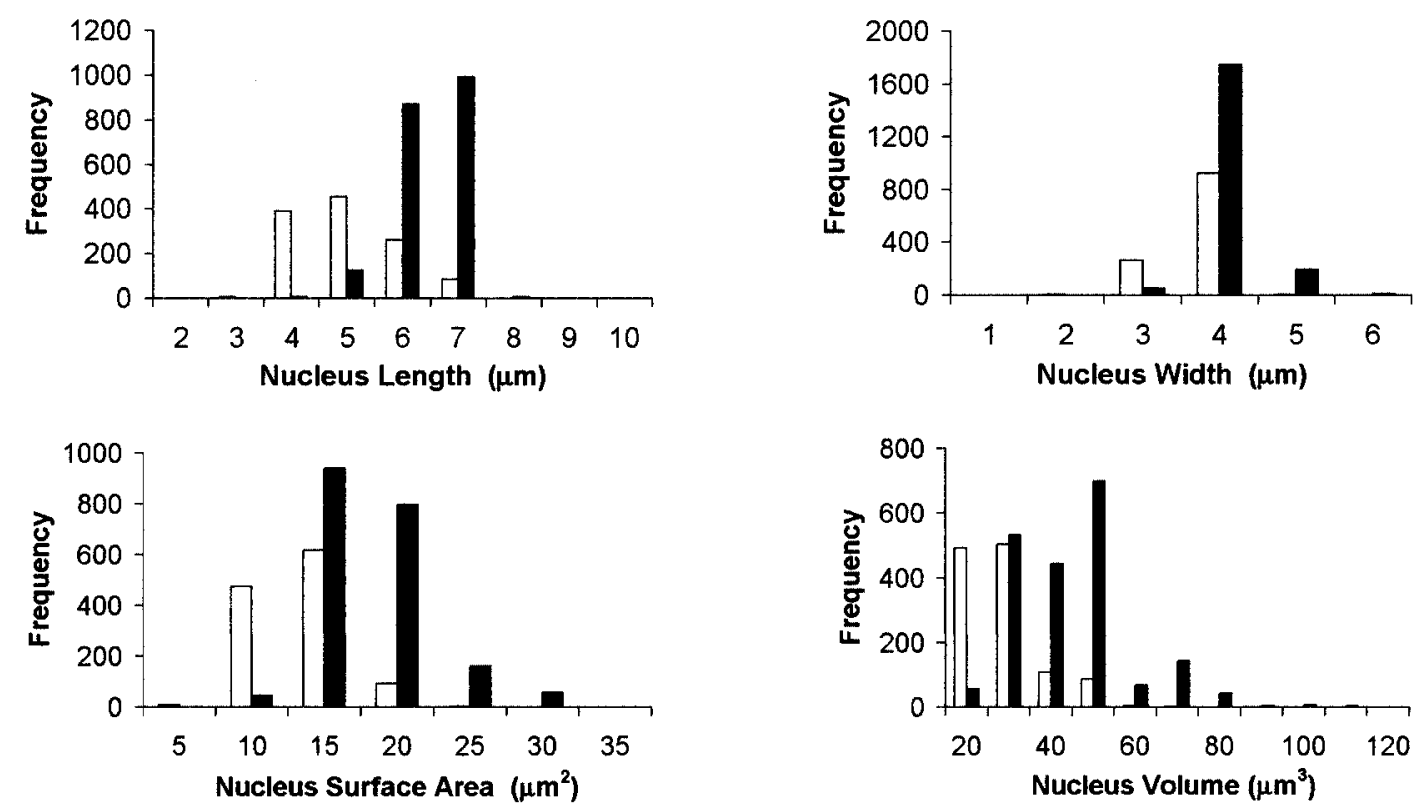

FIGURE 1.-Frequency distribution of length, width, surface area and volume of erythrocyte cells and nuclei $(N$ $=100)$ from 12 diploid and 20 triploid saugeyes. 
TABLE 3.-Unstandardized canonical function coefficients when all variables were entered simultaneously in a single discriminant function analysis. The discriminant score centroid was -2.034 for diploids and 1.221 for triploids. A positive coefficient means that its associated variable is descriptive of the group with the higher mean score on the discriminant function while a negative coefficient means that its associated variable is descriptive of the group with the lower mean score on the discriminant function.

\begin{tabular}{lc}
\hline $\begin{array}{c}\text { Discriminating } \\
\text { variables }\end{array}$ & $\begin{array}{c}\text { Unstandardized canonical } \\
\text { function coefficient }\end{array}$ \\
\hline Cell length & -0.166 \\
Cell surface area & 0.282 \\
Cell volume & -0.020 \\
Nucleus length & -2.004 \\
Nucleus surface area & 1.793 \\
Nucleus volume & -0.338 \\
Constant & -13.974 \\
\hline
\end{tabular}

1992; Kim et al. 1993; Boron 1994; Forest et al. 1994; Flajshans 1997). Measurements of cell and nucleus lengths and widths, and computations of their respective surface area and volume were able to correctly classify $93.8 \%$ of the fish samples as diploid or triploid in this study.

The erythrocyte cell and nucleus lengths and widths in diploid saugeyes is larger than in diploid ayu (Aliah et al. 1991), similar to those in diploid channel catfish (Wolters et al. 1982), but smaller than those in diploid landlocked Atlantic salmon (Benfey et al. 1984). The erythrocyte length (10.4 $\pm 0.9 \mu \mathrm{m})$ in diploid saugeyes is within the range for most teleosts, which is between 8 and $15 \mu \mathrm{m}$ (Fange 1992). In general, erythrocytes are slightly smaller in active species than in nonactive ones, probably because small dimensions facilitate physiological exchanges by a favorable surface to volume ratio (Fange 1992). The considerably low Wilk's lambda (0.27) and the highly significant $\chi^{2}$ values associated with it, suggests that the discriminant score centroids for diploids and triploids differ significantly on the discriminant function, suggesting that the discriminating variables can effectively distinguish between groups (Christensen and Yoesting 1977).

When all eight discriminating variables were used to discriminate between ploidy groups, the cell and nucleus widths were excluded because of very minimal contribution to the discriminant function. Benfey et al. (1984) also observed that cell and nucleus widths were the poorest predictors of ploidy among the six erythrocyte dimensions they measured. Various workers have suggested that triploid fish can be identified based solely on

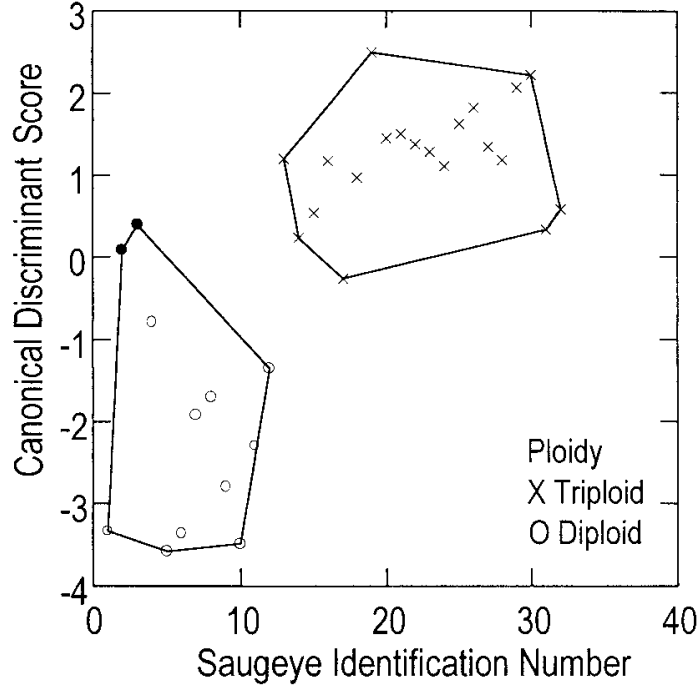

FIGURE 2.-Scatter plot of canonical discriminant scores for individual diploid and triploid saugeye samples. Two of 12 diploids (indicated as two dark points closest to zero on the left $y$-axis) were misclassified while all 20 triploids were correctly classified. In all, $93.8 \%$ of original grouped cases $(N=32)$ were correctly classified.

the length of either cell or nucleus (Wolters et al. 1982; Beck and Biggers 1983; Benfey and Sutterlin 1984). We have not found this to be the case for saugeyes.

Compared with microscopic measurements, cell and nuclear volumes and surface area distributions of blood cells may be analyzed with greater accuracy and speed (more than 200,000 cells in 5 min) by use of either a Coulter Multisizer IIe or Coulter Z2. The former equipment can measure particle sizes of $1-120 \mu \mathrm{m}$, and the latter can measure particle sizes of $0.4-1,200 \mu \mathrm{m}$. Coulter counter analysis is used widely in the aquaculture in-

TABLE 4.-Fisher's linear discriminant function coefficients when all variables were entered simultaneously in a single discriminant function analysis. A sample of unknown ploidy may be classified to the group that gives a higher discriminant score.

\begin{tabular}{lrr}
\hline \multirow{2}{*}{$\begin{array}{c}\text { Discriminating } \\
\text { variable }\end{array}$} & \multicolumn{2}{c}{ Weighting coefficients for: } \\
\cline { 2 - 3 } & \multicolumn{1}{c}{ Diploid } & \multicolumn{1}{c}{ Triploid } \\
\hline Cell length & -46.939 & -47.478 \\
Cell surface area & 20.978 & 21.715 \\
Cell volume & -1.733 & -1.797 \\
Nucleus length & 209.217 & 202.693 \\
Nucleus surface area & -123.789 & -117.954 \\
Nucleus volume & 22.737 & 21.637 \\
Constant & -180.486 & -224.648 \\
\hline
\end{tabular}


dustry for grass carp (Wattendorf 1986). Because the current market price of this equipment ranges from US $\$ 20,000$ to $\$ 33,000$, we envision that only state agencies or aquaculture facilities that engage in large-scale stocking of triploid saugeyes (e.g., Ohio Division of Wildlife) would consider purchasing such equipment. The use of the Coulter counter is still cost-effective compared with flow cytometry services, which are only available in medical schools of large universities. For example, the Comprehensive Cancer Center Analytical Cytometry Laboratory at The Ohio State University (OSU) charges US $\$ 120 / \mathrm{h}$ (25-30 samples) for nonuniversity entities (A. Oberyszyn, OSU, personal communication). Small-scale aquaculture farmers may adopt the technique of manual measurements of erythrocytes using a calibrated ocular micrometer fitted to one eyepiece of a compound light microscope. Measurements of lengths and widths of the cell and nucleus of 100 erythrocytes from one fish require about $1 \mathrm{~h}$ of microscopy work. Data entry and analysis of all samples require about $3 \mathrm{~h}$ of computer time. This workload can be reduced by $50 \%$ because discriminant analysis of cell and nuclear measurements of 50 erythrocytes also showed $93.8 \%$ correct classification. However, only $90.6 \%$ correct classification was obtained when 25 erythrocytes were measured.

Although erythrocyte measurements were not $100 \%$ effective in distinguishing triploid from diploid saugeyes, this technique may still be used by state agencies to identify triploid fish for stocking into lakes and reservoirs where diploid saugeye populations have been stocked previously. The use of this method to identify triploid saugeyes destined for introduction into natural waters where saugeyes are nonendemic or for fish farming purposes should be treated with caution because of possible reproduction from misclassified diploids. The classification success rate of $93.8 \%$ indicates the potential for misclassification. The accuracy of this technique may be improved if other hematological characteristics, such as mean erythrocyte volume, erythrocyte counts, corpuscular hemoglobin, and cytoplasmic hemoglobin concentration, are determined (Benfey and Sutterlin 1984; Benfey et al. 1984; Aliah et al. 1991). These characteristics, including erythrocyte cell and nuclear volumes, could be measured with a standard Coulter counter.

\section{Acknowledgments}

This research was funded by the Ohio Division of Wildlife under Federal Aid in Sport Fish Res- toration, project F-69-P-5, Fish Management in Ohio. We thank Patty Laskowski, William E. Lynch, Jr., and Andrew S. Oberyszyn for technical assistance. Salaries were partly provided by support from state and federal funds to Ohio Agricultural Research and Development Center, The Ohio State University. We acknowledge The Ohio State University Comprehensive Cancer Center Analytical Cytometry Laboratory for assistance; support was provided in part by PHS NIH P30 CA16058.

\section{References}

Aliah, R. S., Y. Inada, K. Yamaoka, and N. Taniguchi. 1991. Effects of triploidy on hematological characteristics, and oxygen consumption in ayu. Nippon Suisan Gakkaishi 57:833-836.

Aliah, R. S., K. Yamaoka, Y. Inada, and N. Taniguchi. 1990. Effects of triploidy on tissue structure of some organs in ayu. Nippon Suisan Gakkaishi 56: 569-575.

Arai, K., K. Matsubara, and R. Suzuki. 1991. Karyotype and erythrocyte size of spontaneous tetraploidy and triploidy in the loach Misgurnus anguillicaudatus. Nippon Suisan Gakkaishi 57:2167-2172.

Armitage, P., and G. Berry. 1994. Statistical methods in medical research, 3rd edition. Blackwell Scientific Publications, Oxford, UK.

Beck, M. L., and C. J. Biggers. 1983. Erythrocyte measurements of diploid and triploid Ctenopharyngodon idella $\times$ Hypopthalmichthys nobilis hybrids. Journal of Fish Biology 22:497-502.

Benfey, T. J., and A. M. Sutterlin. 1984. The haematology of triploid landlocked Atlantic salmon, Salmo salar L. Journal of Fish Biology 24:333-338.

Benfey, T. J., A. M. Sutterlin, and R. J. Thompson. 1984. Use of erythrocyte measurements to identify triploid salmonids. Canadian Journal of Fisheries and Aquatic Sciences 41:980-984.

Bennett, S., and D. Bowers. 1976. An introduction to multivariate techniques for social and behavioural sciences. Wiley, New York.

Billington, N., R. C. Brooks, and R. C. Heidinger. 1997. Frequency and natural hybridization between saugers and walleyes in the Preoria Pool of the Illinois River, as determined by morphological and electrophoretic criteria. North American Journal of Fisheries Management 17:220-224.

Bonar, S. A., G. L. Thomas, and G. B. Pauley. 1988. Evaluation of the separation of triploid and diploid grass carp, Ctenopharyngodon idella (Valenciennes), by external morphology. Journal of Fish Biology 33:895-898.

Boron, A. 1994. Use of erythrocyte measurements to detect natural triploids of spined loach Cobitis taenia (L.). Cytobios 78:197-202.

Burns, E. R., J. F. Anson, W. G. Hinson, J. L. Pipkin, M. G. Kleve, and R. C. Goetz. 1986. Effect of fixation with formalin on flow cytometric measure- 
ment of DNA in nucleated blood cells. Aquaculture 55:149-155.

Cherfas, N. B., B. Gomelsky, N. Ben-Dom, Y. Peretz, and G. Hulata. 1994. Assessment of triploid common carp (Cyprinus carpio L.) for culture. Aquaculture 127:11-18.

Christensen, J. E., and D. R. Yoesting. 1977. The substitutability concept: a need for further development. Journal of Leisure Research 9:188-206.

Cormier, S. M., T. W. Neiheisel, D. E. Williams, and T. R. Tiersch. 1993. Natural occurrence of triploidy in a wild brown bullhead. Transactions of the American Fisheries Society 122:390-392.

Crozier, W. W., and I. J. J. Moffett. 1989. Experimental production of triploid brown trout, Salmo trutta L., using heat shock. Aquaculture and Fisheries Management 20:343-353.

Fange, R. 1992. Fish blood cells. Pages $1-54$ in W. S. Hoar, D. J. Randall, and A. P. Farrell, editors. Fish physiology, volume 12, part B. Academic Press, San Diego, California.

Fiss, F. C., S. M. Sammons, P. W. Bettoli, and N. Billington. 1997. Reproduction among saugeyes $\left(F_{x}\right.$ hybrids) and walleyes in Normandy Reservoir, Tennessee. North American Journal of Fisheries Management 17:215-219.

Flajshans, M. 1997. A model approach to distinguish diploid and triploid fish by means of computerassisted image analysis. Acta Veterinaria Brno 66: 101-110.

Flajshans, M., P. Rab, and S. Dobosz. 1992. Frequency analyses of active NORs in nuclei of artificially induced triploid fishes. Theoretical and Applied Genetics 85:68-72.

Forest, F., C. Oliveira, and E. D. Carvalho. 1994. Ploidy evaluation in the pacu fish, Piaractus mesopotamicus (Pisces, Characiformes): techniques and comments. Revista Brasileira de Biologia 54:31-37.

Harrell, R. M., W. V. Heukelem, and J. H. Kerby. 1998. A comparison of triploid induction validation techniques. Progressive Fish-Culturist 60:221-226.

Humason, G. L. 1979. Animal tissue techniques, 4th edition. Freeman, San Francisco.

Kachigan, S. K. 1986. Statistical analysis. An interdisciplinary introduction to univariate and multivariate methods. Radius Press, New York.

Kim, D. S., C. H. Jeong, and I.-B. Kim. 1993. Induction of all-female triploid in rainbow trout (Oncorhynchus mykiss). Korean Journal of Genetics 15:213218.
Kitamura, H., O. Y. Teong, and T. Arakawa. 1991. Gonadal development of artificially induced triploid red sea bream Pagrus major. Nippon Suisan Gakkaishi 57:1657-1660.

Lin, F., and K. Dabrowski. 1996. Effects of sperm irradiation and heat shock on induction of gynogenesis in muskellunge (Esox masquinongy). Canadian Journal of Fisheries and Aquatic Sciences 53:20672075.

Malison, J. A., and M. A. R. Garcia-Abiado. 1996. Sex control and ploidy manipulations in yellow perch (Perca flavescens) and walleye (Stizostedion vitreum). Journal of Applied Ichthyology 12:189-194.

Malison, J. A., T. B. Kayes, J. A. Held, T. P. Barry, and C. H. Amundson. 1993. Manipulation of ploidy in yellow perch (Perca flavescens) by heat shock, hydrostatic pressure shock, and spermatozoa inactivation. Aquaculture 110:229-242.

Sezaki, K., H. Kobayasi, and M. Nakamura. 1977. Size of erythrocytes in the diploid and triploid specimens of Carassius auratus langsdorfi. Japanese Journal of Ichthyology 24:135-140.

Tambets, J., T. Paaver, A. Palm, A. Pihlak, and R. Gross. 1991. Variability of some cell parameters in di- and triploid rainbow trout Oncorhynchus mykiss R. Eesti Teaduste Akadeemia Toimetised Bioloogia 40:129_ 135.

Thititananukij, S., R. Vejaratpimol, T. Pewnim, and A. W. Fast. 1996. Ethidium bromide nuclear staining and fluorescence microscopy: an alternative method for triploidy detection in fish. Journal of the World Aquaculture Society 27:213-217.

Thorgaard, G. H., and five coauthors. 1982. Triploid rainbow trout identified by flow cytometry. Aquaculture 29:305-309.

Wattendorf, R. J. 1986. Rapid identification of triploid grass carp with a Coulter counter and channelyzer. Progressive Fish-Culturist 48:125-132.

White, M. M., and S. Schell. 1995. An evaluation of the genetic integrity of Ohio River walleye and sauger stocks. Pages 52-60 in H. L. Schramm, Jr., and R. G. Piper, editors. Uses and effects of cultured fishes in aquatic ecosystems. American Fisheries Society, Symposium 15, Bethesda, Maryland.

Wilkinson, L. 1996. SYSTAT 6.0 for Windows: statistics. SYSTAT, Chicago.

Wolters, W. R., C. L. Chrisman, and G. S. Libey. 1982. Erythrocyte nuclear measurements of diploid and triploid channel catfish, Ictalurus punctatus (Rafinesque). Journal of Fish Biology 20:253-258. 